\title{
Identitas Perempuan yang Terbelenggu dalam Gadis Pantai Karya Pramoedya Ananta Toer: Subaltern dalam Konstruksi Sosial Masyarakat Tradisi
}

\section{Syukrina Rahmawati ${ }^{1}$}

\begin{abstract}
Abstrak
Peran perempuan yang selalu tersubordinasikan dan termajinalisasikan telah menjadi isu utama bagi tiap karya sastra atau novel yang muncul di Indonesia, mulai dari novel Siti Nurbaya karya Marah Rusli hingga pada novel Saman karya Ayu Utami. Isu tersebut lahir akibat realitas masyarakat tradisi di Indonesia terutama yang berkaitan dengan pengaruh amat kental dari sistem pemerintahan masa kolonial Belanda. Pulau Jawa termasuk pulau yang menjadi kawasan pusat pemerintahan kolonial khususnya di kawasan Jawa Tengah. Novel yang menarik perhatian pembaca adalah novel-novel Pramoedya Ananta Toer dikarenakan novel-novelnya dianggap sebagai bukti sejarah Indonesia sejak zaman penjajahan hinggan zaman kemerdekaan. Salah satunya adalah novel Gadis Pantai yang pertama kali diterbitkan tahun 2003, tetapi sebelumnya telah beredar sejak tahun 1963. Isinya berisi tentang perwajahan perempuan Jawa yang terbelenggu oleh budaya dan tradisi bangsawan Jawa atas dasar pengaruh kolonial. Permasalahan yang diangkat dalam penelitian novel Gadis Pantai adalah pengaruh kolonial terhadap feodalisme jawa bagi perempuan, relasi penguasa antara sang Bendoro-Mas Nganten (Gadis Pantai), dan keterbatasan ruang aktivitas perempuan yang menjadi kaum perempuan subaltern. Dengan menggunakan teori postkolonial, yakni subaltern yang diusung oleh Gayatri Spivak (1988) maka dapat disimpulkan bahwa peran perempuan hanya ditentukan oleh ideologi priyayi atau keluarga yang menginginkan status sosial anak perempuannya lebih tinggi dari orang tuanya.
\end{abstract}

Kata kunci: identitas, konstruksi sosial, subaltern, poskolonial

\section{Pendahuluan}

Novel Gadis Pantai merupakan salah satu dari sekian banyak novel Pram yang menggambarkan tentang pergulatan kelas-kelas sosial dalam masyarakat yang kental dengan tradisi pada masa kolonial. Ceritanya dilatarbelakangi oleh

\footnotetext{
${ }^{1}$ Penulis adalah dosen di Jurusan Pendidikan Bahasa dan Sastra Indonesia FKIP Universitas Nahdlatul Wathan Mataram
} 
tradisi Jawa yang sangat melekat pada karakter masyarakatnya terutama hubungannya dengan relasi antara priyayi dengan rakyat jelata. Priyayi diwakili oleh tokoh Bendoro, dan rakyat jelata yang kemudian mengalami perubahan status sosial menjadi bangsawan ialah Gadis Pantai (Mas Nganten). Kehidupan Gadis Pantai awal mulanya biasa-biasa saja karena hanya sebagai rakyat biasa yakni anak dari seorang nelayan yang miskin. Akan tetapi, pola hidupnya menjadi berubah drastis ketika ia dipinang dan dijadikan gundik oleh seorang priyayi yang disebut dengan Bendoro.

Bendoro adalah seorang bangsawan (priyayi) yang bekerja pada Belanda. Kekuasaanya sebagai priyayi telah memberikan suatu kewenangan untuk memanfaatkan rakyat kecil, baik untuk menjadi pelayan maupun gundik. Keduanya tetap sama maknanya, hanya saja sebagai gundik akan menaikkan derajat seorang perempuan kampung menjadi perempuan terhormat/bangsawan. Status tersebut dimiliki pada Gadis Pantai (Mas Nganten) setelah dinikahi dan menjadi pemuas "kebutuhan" Bendoro. Kedua orang tuanya terutama ayahnya sangat mendukung pernikahan Bendoro dan Gadis Pantai karena tentu saja agar masyarakat memandang tinggi dan hormat terhadap keluarga mereka. Setelah status Gadis Pantai menjadi wanita bangsawan, ibu-bapaknya dilarang mengunjunginya ke rumah karena memiliki status lebih rendah.

Peralihan gaya hidup Gadis Pantai dari rakyat jelata menjadi bangsawan ternyata tidak membuat hidupnya bahagia. Justru sebaliknya, hidupnya hanya dibayang-bayangi oleh tekanan terus-menerus dari keluarga sang Bendoro. Aturan-aturan yang mengekang ruang lingkupnya sebagai perempuan dibatasi dengan aktivitas-aktivitas yang telah diperuntukkan olehnya sebagai istri sang Bendoro. Selain itu, ibu-bapaknya menjadi bangga saat putrinya diangkat statusnya sebagai Mas Nganten meskipun secara tidak langsung mereka tidak akan dapat berjumpa putri mereka sendiri selama masih bersuamikan sang Bendoro. Di akhir cerita, Gadis Pantai akhirnya dibuang sang Bendoro setelah melahirkan anak perempuan karena dianggap sang anak lebih tinggi status sosialnya daripada ibunya.

Tokoh lain yang juga berperan penting dalam kehidupan Gadis Pantai pascamenikah dengan sang Bendoro adalah bujang wanita (pelayan untuk Mas Nganten). Ia memberitahukan tata cara dalam berperilaku selama berada di lingkungan keluarga sang Bendoro terutama ketika melayani sang Bendoro. Karakter yang dimiliki sang Bujang menguatkan posisinya sebagai rakyat jelata yang bekerja untuk diperintah dan melayani segala kebutuhan majikannya. 
Gaya hidup Gadis Pantai berubah total meskipun ia belum terbiasa, tetapi kondisi dan perilaku keluarga sang Bendoro memaksa dirinya untuk dapat menyesuaikan diri tanpa harus melawan karena hal tersebut bukan tradisi dari bangsawan Jawa. Oleh karena itu, Gadis Pantai hanya dapat melakukan perlawanan dalam diri saja tanpa dapat mengungkapkannya secara langsung. Kondisi demikian adalah cara yang biasa digunakan oleh masyarakat Jawa yang menentang tata cara atau hukum suatu kelas sosial yang lebih tinggi.

Penulis Gadis Pantai (selanjutnya disebut GP) adalah Pramoedya Ananta Toer (selanjutnya disebut Pram) sejak duduk di sekolah rakyat aktif menulis. Sekitar 21 karyanya berupa novel telah diterbitkan. Karya-karyanya sebagian besar mengisahkan tentang kondisi bangsa Indonesia masa kolonial hingga masa prakemerdekaan sehingga bahasanya sering diikuti dengan istilah-istilah Belanda atau Jawa yang amat kental seolah-olah ceritanya mengisahkan suasana Indonesia sebenarnya pada masa itu. Pram dilahirkan dari seorang ibu yang memiliki status sosial yang lebih tinggi dari ayahnya. Ibunya ningrat, dan ayahnya seorang guru dan aktivis PNI cabang Blora. Riwayat hidup Pram sebagai seorang anak yang memiliki orang-tua berbeda kelas sosial memotivasi dirinya untuk menggunakan latar belakang konstruksi sosial masyarakat Jawa sebagai setting cerita dari karya-karyanya.

GP terdiri atas beberapa bagian yang secara keseluruhan menguak posisi perempuan sebagai subaltern dalam ruang lingkup hidup bangswan Jawa yang mengekang dan membatasi aktivitas mereka. Relasi antara penguasa-rakyat jelata mengungkap sisi lain dari sistem feodalisme Jawa yang tak memiliki adab dan jiwa kemanusiaan.

\section{Pembahasan}

\subsection{Pengaruh kehidupan kolonial pada sistem feodalisme Jawa}

Penggambaran sikap dan idealisme seorang bangsawan Jawa lebih ditonjolkan oleh tokoh Bendoro. Bendoro ialah seorang priyayi ${ }^{2}$ yang bekerja sebagai administran pada Belanda. Ia menikahi GP semata-mata hanya untuk

\footnotetext{
2 Priyayi menurut istilah aslinya menunjuk kepada orang yang bisa menyelusuri asal - usul keturunanya sampai kepada raja-raja besar Jawa jaman sebelum penjajahan; yang setengah mitos; tetapi sejak Belanda yang memerintah Jawa lebih dari tiga ratus tahun itu memperkerjakan kaum ini sebagai instrumen asministrasi kekuasaannya pengertian priyayi meluas termasuk orang kebanyakan yang ditarik ke dalam birokrasi akibat persediaan aristokrat asli sudah habis (Geertz, 308).
} 
"kebutuhan" seksual saja, tanpa ada rasa tanggung jawab lain selain mendidik GP sebagai gundik yang bertata-krama seperti priyayi.

Hal ini terbukti dengan pernyataan Ward Keeler dalam artikelnya yang berjudul 'Durga Umayi' dan Dilema Postkolonial (2008) kebanyakan orang Jawa beranggapan bahwa hierarki merupakan ciri fundamental dan prinsip pengatur utama masyarakat manusia. Anggapan ini yang dapat juga diistilahkan dengan konstruksi hegemonik menyatakan bahwa adalah hak dan tanggung jawab pihak yang berstatus lebih tinggi untuk menjalankan kekuasaan atas nama bawahannya, dan adalah hak dan tanggung jawab dari yang berstatus lebih rendah untuk memenuhi kewajiban-kewajibannya dan mematuhi perintahperintah mereka. Keterikatan GP terhadap Bendoro merealisasikan bentuk hierarki pada bentuk feodalisme Jawa yang dipengaruhi oleh kependudukan Belanda pada masa itu.

Kemarin malam ia telah dinikahkan. Dinikahkan dengan sebilah keris. Detik itu ia tahu: kini ia bukan anak bapaknya lagi. Ia bukan anak emaknya lagi. Kini ia istri sebilah keris, wakil seseorang yang tak pernah dilihatnya seumur hidup (GP: 12).

Peristiwa ketika GP dinikahkan oleh sang Bendoro tidak dengan upacara seperti pernikahan biasanya. Akan tetapi, sang Bendoro hanya diwakili oleh sebilah keris yang dianggap sebagai wujud lain dari Bendoro. Dengan begitu, GP secara resmi menjadi istri sang Bendoro dan sekaligus menaikkan derajatnya menjadi bangsawan yang disebut dengan istilah Mas Nganten.

Hal tersebut membuktikan berkuasanya priyayi untuk melakukan kehendaknya terutama terhadap hubungannya dengan perempuan. Relasi kuasa antara priyayi dan rakyat jelata serta antara laki-laki dan perempuan. Hellwig menandaskan bahwa karakter patriarkal dan hierarki sosial masyarakat menjadikan kaum lelaki priyayi pemegang kekuasaan. Kaum perempuan memperoleh rasa harga diri mereka dari peran mereka dalam keluarga, bukan dari posisi sosial mereka (169). "Sebilah keris" yang disetarakan dengan kehadiran "Bendoro" adalah bentuk kekuasaan orang Jawa terhadap segala sesuatu yang bersifat mistik dan percaya terhadap kekuatan gaib. Pemaknaan tersebut berarti kekuasaan atas perempuan atas dasar keseimbangan dalam hubungan laki-laki dan perempuan.

Dalam cerita GP, terdapat ideologi patriarki yang sangat kental dan dijadikan sebagai landasan bagi priyayi untuk sewenang-wenang terhadap 
84| Mabasan - Vol. 5 No. 2 Juli-Desember 2011

perempuan. Terlebih lagi, GP sebagai representasi perempuan Jawa dari kalangan bawah yang terbelenggu oleh stereotipe-stereotipe dan konstrusi sosial yang hanya berpihak pada laki-laki.

Pada suatu hari, karena ia merasa kesepian ia bertanya:

"mbok mengapa di sini tak ada orang tertawa dan tersenyum denganku?"

"Lantas apa gunanya senyum dan tawa pada Mas Nganten. Juga tak baik layani senyum dan tawa mereka. Tahu, Mas Nganten, seorang wanita utama adalah laksana gunung. Dia tidak terungkit kedudukannya, terkecuali oleh tangan Bendoro. Bendoro lebih tidak terungkit, terkecuali Gusti Allah sendiri.” (GP: 82)

Si bujang (mbok) memperingatkan GP bahwa kapasitasnya sebagai istri seorang priyayi hanya untuk melayani segala keinginan Bendoro. Seolah-olah Bendoro dewa bagi GP. Segala aktivitas-aktivitas GP diatur oleh Bendoro mulai dari kursus membatik dan keterampilan lainnya. GP tidak dapat berbuat apa-apa dengan aturan yang mengekangnya karena di dalam rumah sang Bendoro berarti ia telah memasuki dunia baru yang penuh dengan idealis sang penguasa priyayi. Seperti yang dikemukakan oleh Foucault (2008:122), bahwa kekuasaan bukan sesuatu yang diperoleh, dirampas atau dibagi, sesuatu yang digenggam atau dibiarkan lolos; kekuasaan berfungsi berdasarkan unsur yang tak terhitung jumlahnya, dan dalam permainan hubungan yang tak sederajat dan bergerak .

"Lebih dua tahun aku tinggal di kota, sampai akhirnya kau datang. Dan baru sekarang ini aku tahu, orang-orang kota, orang berbangsa itu, begitu takutnya kalau orang tidak lagi menghormatinya. Dan mereka begitu takutnya kalau terpaksa menghormati orang-orang kampung," (GP: 156)

Gadis pantai tahu benar. Bendoro telah tiga hari pergi. Dan ia tahu tepat pula: ia hanyalah hak milik Bendoro. Yang ia tak habis mengerti mengapa ia harus berlaku sedemikian rupa sehingga sama nilainya dengan meja, dengan kursi dan lemari, dengan kasur tempat ia dan Bendoro pada malam-malam tertentu bercengkrama. (GP: 88)

GP merasa ada suatu hal yang dapat dilihat dari posisi dirinya sebagai wanita yang dilahirkan di tengah-tengah subordinasi perempuan yang tiada henti-hentinya. Pikirannya tertuju pada kedudukan sang penguasa-rakyat jelata. Tiada bangsawan jika tidak ada rakyat biasa, tiada yang menindas jika tidak ada yang ditindas, dan tiada yang tersiksa jika tidak ada yang menyiksa. Begitulah 
pembentukan bangsawan Jawa dalam memposisikan diri mereka sebagai pemimpin atau yang lebih unggul dari rakyat biasa. Mereka tidak menjadi terhormat jika tidak ada yang menghormati. Sungguh menjadi suatu kegelisahan bagi GP yang menganggap dirinya tidak pernah berubah meskipun status sosialnya berganti seperti yang diharapkan keluarga.

Selama hidup di lingkungan priyayi, GP tidak pernah merasakan ketentraman dalam dirinya. Selalu ada bentuk perlawanan dalam diri meskipun tidak langsung diungkapkan pada sang Bendoro. Namun, ketidaknyamanannya sebagai istri priyayi sedikit tidak telah mengubah kegiatan yang biasa dilakukan anak nelayan menjadi perempuan yang terampil dalam hal pekerjaan rumah tangga.

"Terima kasih, mBok. Terima kasih. Ke manakah biasanya Bendoro pergi sampai berhari-hari begini?

"Ah, Mas Nganten, itu urusan pria dengan pekerjaannya. Jangan ikut campur, karena wanita tak tahu apa-apa tentang itu. kita hanya tahu daerah kita sendiri: rumah tangga yang harus kita urus." (GP: 77—78)

GP sebagai gadis yang polos dan telah menjadi istri seorang laki-laki perlu merasa berhak untuk mengetahui tujuan kepergian suaminya Bendoro setiap harinya. Sementara itu, seorang priyayi (laki-laki) dalam pandangan Jawa adalah seseorang yang memiliki kewenangan penuh atas apa yang ia miliki dalam keluarganya. Dengan demikian, citra perempuan Jawa sesungguhnya memiliki peranan yang begitu besar pada kehidupan laki-laki terutama saat dihadapkan dengan sistem nilai yang feodal dan berkaitan dengan masalah ketegangan kolonial.

Nilai-nilai feodal yang tertanam pada budaya Jawa didasari oleh hubungan para priyayi terhadap pemerintahan kolonial saat itu. Pengaruh sistem memerintah atau cara memimpin begitu melekat pada priyayi (baca: laki-laki). Segala sisi kehidupan menjadi terkesan diatur tanpa ada kompromi dari pihak lain terutama perempuan. Oleh karena itu, perempuan mengalami rasa beban yang begitu berat atas sistem-sistem yang dibawa oleh pengaruh kolonial terhadap para priyayi. Sistem feodal yang menguasai perempuan tersebut dijadikan laki-laki (priyayi) sebagai alat untuk melampiaskan kekuasaannya terhadap hak-hak yang dimiliki seorang bangsawan Jawa.

"Apa yang oh? Kau ini aku tertawa tak boleh, begini salah, begitu salah, apa yang oh? Kami memang orang miskin, dan di mata orang kota 
Mabasan - Vol. 5 No. 2 Juli-Desember 2011

kemiskinan pun kesalahan. Aku masih ingat pada hari-hari pertama. Bendoro bilang kami orang-orang jorok, tak tahu iman, itu miskin, kau mengerti agama?" (GP: 159)

Dan sekarang Gadis Pantai tertegun. Ia mulai mengerti di sini ia tak boleh punya kawan seorang pun yang sederajat dengannya. Ia merasai adanya jarak yang begitu jauh, begitu dalam antara dirinya dengan wanita yang sebaik itu yang hampir-hampir tak pernah tidur menjaga dan mengurusnya, selalu siap lakukan keinginannya, selalu siap terangkan segala yang ia tak paham, bisa mendongeng begitu memikat tentang Joko Tarub, dan bisa mengusap bahunya begitu sayang bila ia siap hendak menangis. (GP: 46)

Mulai dari sikap keluarga hingga pada sikap Bendoro terhadap GP saat pertama kali perjumpaan, GP mulai agak sedikit mengerti mengenai kedudukannya dihadapan Bendoro yang begitu agung di mata keluarganya. Keagungannya seolah tak ada yang bisa menandingi kecuali atas adanya kehendak Tuhan. Segala apa yang menjadi pemikiran dan ideologi yang dimiliki oleh seorang priyayi merupakan sesutau yang sudah baku dan wajib dipatuhi oleh para hamba sahaya, kaum proletat, dan kaum miskin lainnya yang ada di wilayah kekuasaannya. Segala aspek kehidupan dikuasai oleh priyayi, baik di bidang politik, agama, bahkan urusan rumah tangga sekalipun, semuanya sudah diatur sedemikian rupa sesuai dengan kewenangan penuh yang dimiliki.

Keterkukungan GP dari awal hingga kemudian ia kalah meskipun merasa lega karena akhirnya ia diceraikan oleh sang Bendoro setelah melahirkan anak perempuan, didasari oleh sifat adanya dualisme ${ }^{3}$ dalam sistem politik, ekonomi, sosial, dan kebudayaan di Indonesia. Pengaruh akibat ketumpangtindihan terhadap budaya kolonial berdampak pada semua lapisan struktur masyarakat Indonesia. Reaksi Bendoro terhadap GP semenjak anak perempuan lahirnya menjadi sesuatu yang wajar apabila direlevansikan dengan hal sebelumnya, karena reaksi tersebut memang diharuskan seperti itu sebagai akibat status sosial yang lebih tinggi.

\footnotetext{
${ }^{3}$ Di satu pihak masyarakat setempat hidup dalam dan dengan sistem politik, ekonomi, sosial, dan kebudayaan tradisional merea masing-masing, tetapi di pihak lain mereka juga harus hidup dengan dan dalam tatanan kolonial yang berlaku bagi semua sektor di atas pula (Faruk, 2007: 9)
} 


\subsection{Relasi Bendoro-Mas Nganten Sebagai Representasi "Pengakuan"}

Sejak awal hubungan sang Bendoro dan GP (Mas Nganten), tidak pernah terlihat harmonis. Keharmonisan yang tampak hanya rekayasa dan rancangan yang dibuat oleh Bendoro. Hal tersebut menunjukkan bentuk keberhasilannya sebagai priyayi sekaligus laki-laki yang mampu mengendalikan dan mengontrol perempuan (istrinya) untuk menjadi seperti apa yang diinginkan. Hubungan ini dapat dikategorikan hubungan antara 'penjajah' dan yang 'dijajah', 'penindas' dan 'yang menindas', serta 'penguasa' dan 'rakyat jelata'. Relevan dengan teori poskolonial, yakni hubungan antara 'penjajah' dan 'terjajah'.

Seperti yang dikemukakan oleh Lorde dalam Trinh T.Minh-Ha (1995: 266) Women of today are still being called upon to stretch across the gap of male ignorance, and to educate men as to our existence and our needs. This is an old and primary tool of all oppressors to keep the oppressed occupied with the master's concerns. Dengan demikian, posisi GP (perempuan) merupakan suatu yang diakui sendiri meskipun secara tidak langsung dan pembenaran terhadap dominasi laki-laki terhadap perempuan. Laki-laki sebagai 'penindas' berarti memiliki pandangan bahwa laki-laki memang seharusnya menjadi pemimpin bagi perempuan sebagai 'tertindas'. Tradisi mengambil perempuan sebagai gundik atau selir merupakan salah satu tradisi di Jawa yang harus dipatuhi oleh semua kalangan, terutama saat masa kolonial. Inilah yang melatarbelakangi adanya 'pengakuan' pada diri laki-laki maupun perempuan pada masa itu untuk menunujukkan eksistensi sebagai manusia yang hidup.

Waktu Bendoro terlelap tidur, dengan kepala pada lengannya, ia mencoba mengamati wajahnya. Begitu langsat, pikirnya. Orang mulia, pikirnya, tak perlu terkelantang di terik matari. Betapa lunak kulitnya dan selalu tersapu selapis ringan lemak muda! Ingin ia rasai dengan tangannya betapa lunak kulitnya, seperti ia mengemasi si adik kecil dulu. Ia tak berani. Ia tergeletak diam-diam di situ tanpa berani bergerak, sampai jago-jago di belakang kamarnya mulai berkokok. Jam tiga. Dengan sigap Bendoro bangun. Dan dengan sendirinya ia pun ikut serta bangkit (GP: $33)$.

Peristiwa setelah melalui malam pertama yang begitu mengejutkan GP, ia merasa aneh dan asing sehingga ketika sang Bendoro tertidur ia berpikir bahwa ternyata ia telah dimiliki oleh laki-laki yang baru dikenalnya sehari. Begitu kagumnya ia melihat sosok tubuh priyayi di hadapannya. 
Mabasan - Vol. 5 No. 2 Juli-Desember 2011

Seiring berjalannya waktu, GP tak dapat menyembunyikan kegelisahannya atas pola hidup yang ia jalani pascamenikah dengan sang Bendoro. Meskipun statusnya telah membanggakan keluarga, tetapi pikiran, perasaan, dan sikapnya masih seperti waktu ia hidup bersama keluarganya. Ia merindukan kebebasan saat menjadi anak seorang nelayan.

"Betapa kasar tanganmu."

"Sahaya Bendoro," Gadis Pantai berbisik dengan sendirinya. "Di sini kau tak boleh kerja. Tanganmu harus halus seperti beludru. Wanita utama tak boleh kasar.” (GP: 32)

Semenjak itu, ia selalu dijuluki 'wanita utama' meskipun ia sendiri tidak mengerti sebagai 'wanita utama' tapi ruang lingkupnya di dalam rumah justru dibatasi. Ruang gerak aktivitas GP tidak sebebas yang ia pikirkan. Meskipun ia tidak diperbolehkan bekerja seperti waktu di kampung nelayan, tetapi intensitasnya untuk melakukan kegiatan-kegiatan yang tidak membuat tangannya menjadi kasar telah mengekang kreativitas yang ia miliki sebelumnya.

Sang Bendoro adalah tokoh yang superior dan GP adalah tokoh yang inferior. Dengan kemelut peran diri masing-masing sebagai laki-laki dan perempuan, keduanya memiliki kesadaran sendiri mengenai kedudukan dan kekuasaan yang ada pada diri masing-masing. Kesuperioran Bendoro ditunjukkan dengan kekuasaannya dalam mengatur, mengendalikan, dan mengontrol GP dan seluruh yang ada di rumah tanpa ada campur tangan orang lain. Selain itu, hal demikian pula ditunjukkan saat berlangsungnya pernikahan antara dirinya dengan GP. Bendoro tidak hadir dalam pernikahan, tetapi karena dalam tradisi Jawa kuno, seorang perempuan dikatakan menikah dengan seorang laki-laki dapat ditandai hanya dengan diwakili oleh barang pusaka yang sudah menjadi kepercayaan dan keyakinannya. Untuk pemahaman lebih lanjut mengenai relasi antara Bendoro dan GP (Mas Nganten), maka dapat dilihat analisis yang terdapat pada cover novel tersebut berikut ini. 


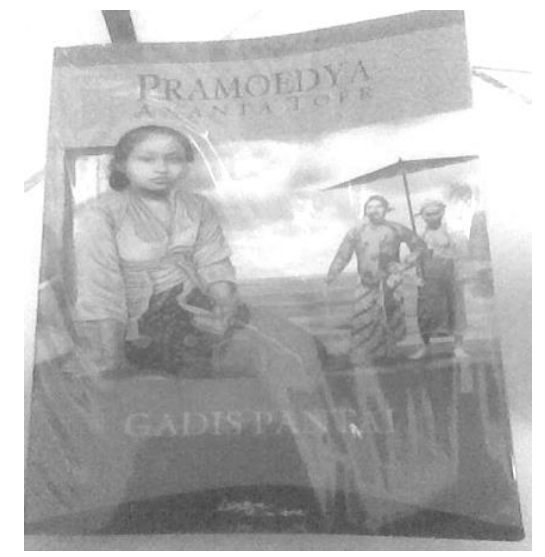

Pada cover terlihat gambar seorang gadis Jawa (GP) yang berpakaian ala tradisional Jawa dengan duduk khas wanita Jawa pula. Sikap dan ekspresi gambar perempuan memperlihatkan bahwa ruang gerak perempuan hanya terdapat di dalam rumah saja (tampak setting dapur di tangan sebelah kanan) terlebih di sebelahnya terlihat dari kejauhan terdapat gambar laki-laki Jawa (priyayi) dengan ekspresi berkacak pinggang dengan sebelah tangan ditemani pelayannya. Hal tersebut memperlihatkan representasi perempuan yang 'tidak berdaya' dan seolah olah pasrah terhadap segala keputusan sang Bendoro mengenai hidupnya meskipun tampak ekspresi di wajahnya yang terlihat hampa dan ada kegelisahan yang dipendam.

Pemaparan mengenai isi cover tersebut relevan dengan isi cerita secara keseluruhan. Di akhir cerita memang tokoh GP menjadi kalah karena setelah melahirkan anak perempuan, ia langsung dibuang oleh Bendoro. Akan tetapi, di sisi lain dia menang karena hari-harinya tidak lagi di selimuti oleh segala peraturan-peraturan yang dibebankan padanya dari sang Bendoro. Konstruksi sosial masyarakat tradisi (Jawa) mengakibatkan hak-haknya sebagai manusia dipenjarakan dan tak dapat diperjuangkan selama hati dan tubuhnya dikuasai oleh laki-laki terutama pada golongan bangsawan (priyayi).

Sebagaimana diketahui, bahwa di dalam pembentukan sistem feodal suatu pemerintahan baik di lingkungan kecil maupun besar terutama pada perempuan, tidak semuanya merasa tersiksa dan tertindas atas hukum-hukum dan aturan-aturan yang telah dibuat oleh pihak laki-laki atau bangsawan atas pengaruh sistem kolonial. Ada perempuan-perempuan lain yang merasa semuanya pantas diperoleh selama masih bertahan hidup dalam kemelut kehidupan yang ditetapkan oleh para priyayi tersebut. Tokoh lain tersebut diantaranya Mardinah dan si mBok (keduanya menjadi pelayan di rumah 
90| Mabasan - Vol. 5 No. 2 Juli-Desember 2011

Bendoro). Akan tetapi, tokoh Mardinah adalah perempuan yang memiliki dendam pribadi terhadap aturan yang mengikat sehingga ia lampiaskan dengan GP agar GP menyadari bahwa dirinya sesungguhnya tidak berhak untuk menjadi priyayi.

"Tidak. Tidak terserah padamu semata-mata. Keluar kau dari kamar ini! Jangan masuk lagi. Keluar!

Lenyaplah tawa dari wajah Mardinah. Dengan mata berapi-api ditantangnya Gadis Pantai dan dengan suara mengancam ia menyatakan, "Tidak mungkin orang kampung memerintah anak priyayi. Tidak bisa. Tidak mungkin." (GP: 127)

"Bodohnya Mas Nganten ini. setiap istri pembesar mempunyai kesenangannya, yang satu main ceki, yang lain main cinta, tapi Mas Nganten cuma sibuk di rumah seperti pesakitan."

Gadis Pantai terhenti membatik. Sekaligus tergambar dalam ingatannya seorang pria bertubuh tegap, tidak begitu tinggi, kulitnya kehitaman, dan suaranya begitu tegas dan yakin, dan bijaksana: tamu Bendoro yang ia tak ketahui namanya. Ia tersenyum sedikit.

“Sahaya juga bekas istri pembesar, Mas Nganten."....

"Ingatlah pada Bendoro, karena otakmu sedang diganggu oleh iblis." (GP: 129-130)

Mardinah mencoba menggoda GP untuk melakukan sesuatu yang melawan Bendoro karena ia merasa dendam terhadap apa yang juga telah terjadi padanya. Seolah-olah ia menyadarkan GP bahwa cepat atau lambat statusnya yang kini sedang menjadi kebanggaan keluarga akan punah seketika karena Bendoro pasti akan memperistri perempuan-perempuan lainnya sebagai selir dan akan membuangnya suatu saat nanti. Akan tetapi, cara yang digunakan oleh Mardinah memang membuat GP merasa terganggu meskipun ia sadar akan hal itu.

Adanya tokoh-tokoh Mardinah dan si mBok dalam cerita tersebut membuktikan adanya relasi kuasa antara Bendoro dan GP sebagai Mas Nganten. Dalam pandangan teori poskolonial, dikatakan bahwa adanya hubungan antara 'penindas' dan 'yang tertindas' adalah salah satu aspek yang melatarbelakangi adanya 'pengakuan' dari masing-masing pihak untuk menunjukkan diri pribadi terhadap status sosial yang dimiliki. 


\subsection{Gadis Pantai: Can The Subaltern Speak?}

Perempuan Jawa yang direpresentasikan oleh GP adalah tokoh yang subaltern. Menurut Gramsci, kelas-kelas subaltern adalah mereka yang disubordinasikan oleh struktur kekuasaan yang dominan, dipinggirkan dari representasi politik ${ }^{4}$. GP adalah korban dari sistem penguasa yang memanfaatkannya sebagai gundik atau selir yang kapan saja dapat dibuang begitu saja tanpa ada jaminan hidup yang lebih baik. Kesadaraan menjadi selir dimiliki oleh semua perempuan Jawa pada masa itu (masa kolonial). Para priyayi (laki-laki) dan kolonial berhak atas mereka.

Spivak's analysis of power relations in colonial and postcolonial India reveals dramatic and persistent gender inequalities. "Both as object of colonialist historiography and as subject of insurgency, the ideological construction of gender keeps the male dominant. If, in the context of colonial production, the subaltern has no history and cannot speak, the subaltern as female is even more deeply in shadow" ("Subaltern" 287).

Berdasarkan pernyataan yang dikemukakan Spivak, GP adalah korban dari ideologi kolonial dan bentuk kekuatan dominasi laki-laki terhadap perempuan. GP menjadi bayang-bayang bagi Bendoro, seperti tidak bernyawa tetapi secara konkret karena Bendoro hanya membutuhkan tubuh GP bukan perannya sebagai perempuan (istri) yang berhak memperoleh kebahagiaan dan kesejahteraan hidup. Kondisi ini didukung dengan postkolonial. Posisi perempuan pada masa kolonial terbungkam oleh praktik-praktik sistem pemerintahan yang diterapkan oleh kolonial bahwa perempuan hanya sebagai pelengkap kebutuhan laki-laki.

"Wanita utama mesti belajar mesti bisa melegakan hati Bendoro, ingatingatlah itu." (GP: 35)

"Lantas apa yang dipunyai perempuan kota?"

"Tak punya apa-apa, Mas Nganten kecuali,"

"Ya?"

"Kewajiban menjaga setiap milik lelaki."

"Lantas milik perempuan itu sendiri apa?"

“Tidak ada Mas Nganten. Dia sendiri hak milik lelaki." (GP: 87-88)

\footnotetext{
${ }^{4}$ Dalam Budianta pada artikelnya yang berjudul Perempuan, Seni Tradisi, dan Subaltern (2005: 90)
} 
92| Mabasan - Vol. 5 No. 2 Juli-Desember 2011

Kata-kata 'kewajiban menjaga setiap milik lelaki' adalah suatu yang tertanam dibenak para perempuan di masa kolonial apalagi wanita yang terlanjur mengenyam sekelumit persoalan tradisi, dalam hal ini nilai-nilai feodal budaya Jawa. Secara keseluruhan, tokoh GP menggambarkan perempuan yang terbelenggu atas dasar perubahan status yang diimpi-impikan oleh keluarganya. Ia berpikir dengan menjadi istri seorang priyayi segalanya dapat ia lakukan seperti saat ia hidup dengan orang tuanya. Akan tetapi, justru sebaliknya, ia hanya memperoleh kekangan dari keluarga sang Bendoro terutama dari sang Bendoro sendiri. Menurut Karlina Leksono Supeli dalam Budianta (2005: 99), keluarga membatasi perempuan, menuntut atau bahkan memperbudak perempuan, tetapi pemahamannya tentang siapa dirinya, rasa gembira, dan kebutuhannya dibentuk oleh subjek seorang ibu, seorang istri, identitas yang tidak dapat dipisahkan begitu saja dari rasa kediriannya (nyata atau yang dibayangkan) tanpa membuat dirinya terkoyak.

Dengan demikian, ketika Spivak mempertanyakan Can the Subaltern Speak? Maka GP menjadi salah satu dari kaum perempuan subaltern yang hanya bisa mengikuti alur pikiran sang Bendoro dan terpaksa melakukan segala yang diperintahkan Bendoro demi statusnya sebagai istri priyayi. selain mendapat tekanan dari aturan-aturan sang Bendoro, ia juga mendapat tekanan dari seorang perempuan lain yang mengaku saudara Bendoro yakni Mardinah, yang mengungkapkan bahwa GP termasuk perempuan kampung yang tidak pantas untuk tinggal di rumah seorang priyayi meskipun statusnya telah berubah menjadi priyayi (bangsawan).

\section{Simpulan}

Berdasarkan uraian sebelumnya, dapat disimpulkan bahwa pertama, tokoh GP menjadi representasi perempuan Jawa yang hidup di bawah tekanan nilai-nilai feodal yang berada dalam pengaruh kolonial Belanda dikarenakan sang Bendoro adalah pegawai administrasi Belanda. Ruang geraknya menjadi sangat terbatas dan dikendalikan. Sistem pemerintahan yang dibawa oleh Belanda mendarahdaging di kalangan bangsawan Jawa. Landasan postkolonial adalah adanya hubungan antara penjajah dan yang dijajah, begitu pula kaitannya dengan Bendoro dan GP (Mas Nganten). Hubungan antara keduanya dapat dikategorikan sebagai penguasa dan rakyat jelata, penguasa yang berkuasa atas hak-hak dan aktivitas-aktivitas GP yang telah menjadi istri atau gundiknya. 
Kedua, tokoh GP juga bentuk dari kaum perempuan subaltern yang telah dikonstruk oleh tradisi sekaligus dipaksa menjadi produk kolonial melalui Bendoro sebagai seorang priyayi. Akibatnya, GP sebagai perempuan telah menjadi korban dari praktik penindasan sang Bendoro dan membuat eksistensinya terbelenggu hanya karena hak-haknya yang dikekang secara paksa.

\section{DAFTAR PUSTAKA}

Budianta, Melanie. 2005. "Perempuan, Seni Tradisi, dan Subaltern: Pergulatan di Tengah-tengah Lalu-lintas Global-Lokal" dalam Hayat \& Surur (Ed). Perempuan Multikultural: Negoisasi dan Representasi. Jakarta: Desantara

Castle, Gregory. 2007. The Blackwell Guide to Literary Theory. Australia: Blackwell Publishing

Faruk. 2007. Belenggu Pasca-kolonial: Hegemoni \& Resistensi dalam Sastra Indonesia. Yogyakarta: Pustaka Pelajar

Foucault, Michel. 2008. Ingin Tahu Sejarah Seksualitas (Terjemahan dari La Volonté de Savoir: Histoire de la Sexualité). Jakarta: Yayasan Obor Indonesia

Geertz, Clifford. 1989. Abangan, Santri Priyayi dalam Masyarakat Jawa (terjemahan dari The Religion of Java). Jakarta:Pustaka Jaya.

Hellwig, Tineke. 2003. In The Shadow of Change: Citra Perempuan dalam Sastra Indonesia. Jakarta: Desantara.

Keeler, Ward. 2008. "Durga Umayi dan Dilema Postkolonial" dalam Keith Foulcher \& Tony Day (Ed). Sastra Indonesia Modern: Kritik Postkolonial Edisi Revisi Clearing Space. Jakarta: Yayasan Obor Indonesia

T.Minh-Ha, Trinh. 1995. "Writing Postcoloniality and Feminism" dalam Bill Ashcroft, Gareth Griffiths and Helen Tiffin (Ed). The Postcolonial Studies Reader. London: Routledge

Toer, Pramoedya Ananta. 2009. Gadis Pantai. Jakarta: Lentera Dipantara 